\title{
TEKNOLOGI PEMBUATAN TEPUNG PORANG TERMODIFIKASI DENGAN VARIASI METODE PENGGILINGAN DAN LAMA FERMENTASI
}

\section{PROCESSING TECHNOLOGY OF PORANG FLOUR MODI FIED WITH THE VARIATIONS OF MILLING METHODS AND LONG FERMENTATION}

\author{
Muh. Agus Ferdian* dan Randhiki Gusti Perdana \\ Prodi Teknologi Industri Pertanian, Fakultas Teknologi Pertanian, Institut Pertanian Malang \\ *Email korespondensi: andrew.ftp@unej.ac.id
}

Diterima 22-03-2021, diperbaiki 27-05-2021, disetujui 31-05-2021

\begin{abstract}
Indonesia has many natural resources that have not been properly addressed or utilized, one of them is the Porang tuber. Porang tuber has the characteristic of araceae which has a high calcium crystal oxalate, that is $0.19 \%$. These substances can cause itching and burning sensation in the mouth, even harm our kidneys. Thus, technology is needed to reduce the calcium oxalate content of Porang flour by modifying the processing method. The aims of this study are to obtain the most optimal technology for making modified porang flour with a decrease in optimal calcium oxalate levels and to know the physicochemical characteristics of the modified porang flour.. The research was carried out in three stages, namely the production process of Porang flour modified with the variations of wet and dry milling methods, and the fermentation time that were 0, 6, 12, 18 and 24 hours. Characteristics of modified Porang flour include chemical and physical, and the final stage is data analysis. The result showed that the modified Porang flour processing technology with the highest decrease in calcium oxalate content was the wet milling method with the fermentation time of 18 hours and the value of $62.28 \%$. The chemical characteristics of the modified proximate content of Porang flour showed that the levels of protein, fat, water, ash and carbohydrates were $9.34 \%, 0.49 \%, 12.50 \%, 3.59 \%$ and $74.09 \%$ respectively. The physical characteristics of porang flour are brownish white, a distinctive aroma of flour, powder form and a slightly salty taste.
\end{abstract}

Keywords: porang tuber, flour, modification, calcium oxalate

\begin{abstract}
ABSTRAK
Indonesia memiliki banyak sumber daya alam yang belum mendapatkan perhatian atau termanfaatkan dengan baik, salah satunya adalah umbi porang. Umbi porang memiliki ciri araceae yaitu adanya kristal kalsium oksalat yang tinggi yaitu sebesar $0,19 \%$. Substansi ini dapat menyebabkan gatal dan rasa panas di mulut bahkan dapat membahayakan ginjal. Sehingga dibutuhkan teknologi untuk menurunkan kandungan kalsium oksalat dari tepung porang dengan cara memodifikasi cara pengolahannya. Tujuan dari penelitian ini adalah untuk mendapatkan teknologi pembuatan tepung porang termodifikasi yang paling optimal dalam dengan penurunan kadar kalsium oksalat optimal dan mengetahui karakteristik fisikokimia tepung porang termodifikasi yang dihasilkan. Penelitian dilaksanakan melalui tiga tahap yaitu pembuatan tepung porang termodifikasi dengan variasi perlakukan metode penggilingan basah dan kering, serta perlakuan lama fermentasi $0,6,12,18$ dan 24 jam. Karakteristik tepung porang termodifikasi meliputi kimia dan fisik dan tahap akhir yaitu analisis data.
\end{abstract}


Hasil penelitian menyebutkan bahwa teknologi pembuatan tepung porang termodifikasi dengan penurunan kadar kalsium oksalat tertinggi adalah perlakuan metode penggilingan basah dengan lama fermentasi 18 jam dengan nilai 62,28\%. Karakteristik kimia berupa kandungan proksimat tepung porang termodifikasi hasil analisa menunjukkan kadar protein, lemak, air, abu dan karbohidrat secara berurutan adalah $9,34 \%, 0,49 \%, 12,50 \%, 3,59 \%$ dan 74,09\%. Karakteristik fisik tepung porang berupa putih kecokelatan, aroma khas tepung, bentuk berupa sebuk dan rasa cenderung agak asin.

Kata kunci: umbi porang, tepung, modifikasi, kalsium oksalat

\section{PENDAHULUAN}

Indonesia memiliki kekayaan alam yang melimpah yang menjadikannya sebagai Negara dengan mega biodiversiti. Sehingga hal tersebut menyebabkan banyak sumber kekayaan alam yang belum secara maksimal mendapatkan perhatian atau termanfaatkan. Komoditas yang dimiliki Indonesia salah satunya adalah umbi porang yang justru lebih banyak menjadi perhatian Negara oleh negara lain dibandingkan di negara sendiri. Berdasarkan data yang berhasil dihimpun pada semester pertama 2021, ekspor porang Indonesia mencapai angka 14,8 ribu ton, dimana angka ini melampaui jumlah ekspor semester pertama pada 2019 dengan jumlah 5,7 ribu ton. Hal ini menunjukkan kenaikan aktivitas ekspor sebanyak 160 persen. Adapun negaranegara yang menerima suplai ekspor utama porang dari Indonesia diaantaranya Cina, Vietnam, dan Jepang (Muhtarom, 2021).

Umbi porang (Amorphophallus oncophyllus) tergolong kedalam tanaman umbi famili Araceae dengan kandungan yang dominan didalamnya yaitu glukomanan 5\%-65\%, kadar air 79,7\%, pati $2 \%$, dan serat kasar 8\% (Harijati et al., 2011). Kandungan glukomanan yang besar terdapat pada umbi porang membuat tanaman ini menjadi komoditi yang banyak dicari oleh pelaku industri terutama industri pangan dan kesehatan (farmasi). Selain sebagai bahan dalam industri makanan, glukomanan juga banyak digunakan sebagai bahan industri non pangan seperti penguat kertas, bahan lem, bahan edible film, dan masih banyak lagi kegunaan (Widari and and Rasmito, 2018). Selain itu ciri dari umbi porang yaitu Araceae atau terdapatnya kristal kalsium oksalat yang tinggi sebesar $0,19 \%$. Substansi ini dapat menyebabkan gatal dan rasa panas di mulut (Arifin, 2001).

Kandungan kalsium oksalat yang tinggi akan berbahaya apabila masuk kedalam tubuh manusia dan memberikan efek kristalisasi di dalam ginjal (Nakata, 2003). Sehingga diperlukan berbagai upaya dalam mengurangi atau mereduksi kalsium oksalat agar mencapai batas minimum dalam pemakaian konsumsi. Diantara caranya adalah perendaman larutan $\mathrm{NaCl}$ (Widjanarko, 2011) dan asam organik (Wardani dan Handrianto 2019). Hasil dari perlakuan diketahui memiliki efek dalam penurunan kalsium oksalat yang berbedabeda. Namun, yang menjadi perhatian adalah keseluruhan perlakuan tersebut memberikan efek biaya yang tinggi, sehingga akan berpengaruh pada sisi ekonomis dari tepung porang.

Alternatif upaya yang dapat dilakukan dalam penuruanan kalsium oksalat yang lebih efisien adalah perbedaan metode dalam penggilingan (basah dan kering). Teknologi yang digunakan dalam menurunkan kadar asam oksalat dilakukan dengan secara fisik/mekanis (Faridah et al., 2012; Sitompul 
et al., 2018) dan kimia (Widari dan Rasmito, 2018). Perlakuan fermentasi dengan pengggunaan bakteri asam laktat diketahui mampu menurunkan kadar kalsium oksalat. Sistem kerja yang dimiliki dari proses fermentasi dalam penurunan kadar kalsium oksalat adalah terjadinya hidrolisis akibat adanya enzim pemecah asam oksalat yang dimiliki oleh mikroorganisme di dalam bakteri asam laktat. Penggunaan asam diketahui mampu menurunkan total oksalat pada umbi kimpul sebesar sebesar 66\% (Agustin et al., 2017)

Penelitian ini termasuk dalam kategori penelitian awal dan relatif pada tahap uji coba, sehingga pelaksanaan sebelumnya belum dilakukan dan berfokus pada pelaksanaan yang akan dilakukan yaitu dengan melakukan fermentasi BAL pada umbi porang. Penelitian ini bertujuan untuk mendapatkan teknologi pembuatan tepung porang termodifikasi yang paling optimal dalam dengan penurunan kadar kalsium oksalat optimal dan mengetahui karakteristik fisikokimia tepung porang termodifikasi yang dihasilkan.

\section{METODE PENELITIAN}

Alat yang digunakan dalam pembuatan tepung porang antara slicer manual, bak fermentasi, blender. Bahan penelitian yang digunakan adalah umbi porang yang diperoleh dari petani di Desa Donomulyo Kabupaten Malang sebagai bahan utama, BAL (Bakteri Asam Laktat) dari laboratorium Institut Pertanian Malang yang diperoleh dari larutan air cucian beras melalui metode fermentasi (Leko et al., 2018). Sedangkan untuk bahan analisis yang digunakan adalah aquadest, asam klorida ( $\mathrm{HCl})$, kalium sulfat (K3SO4), magnesium sulfat (MgSO4), natrium hidroksida $(\mathrm{NaOH})$, asam benzoat $\left(\mathrm{H}_{3} \mathrm{BO}_{4}\right)$, eter, benzena, metilen red, brom kresol green dan aceton.

Penilitian dilakukan dengan menggunakan Rancangan Acak Lengkap dengan 2 faktor yaitu metode penggilingan (basah dan kering) dan lama fermentasi (6, 12, 18 dan 24 jam) dengan dua kali ulangan. Rancangan penelitian disajikan pada Tabel 1.

Tabel 1. Rancangan Penelitian

\begin{tabular}{lcccc}
\hline \multirow{2}{*}{ Metode Penepungan $(\mathbf{P})$} & \multicolumn{4}{c}{ Lama Fermentasi $(\mathbf{T})$} \\
\cline { 2 - 5 } & 6 Jam & 12 Jam & 18 Jam & 24 Jam \\
\hline Penggilingan basah & T1P1 & T2P1 & T3P1 & T4P1 \\
Penggilingan kering & T1P2 & T2P2 & T3P2 & T4P2 \\
\hline
\end{tabular}

Penelitian dilaksanakan melalui tiga tahapan yaitu pembuatan tepung porang termodifikasi, karakteristisasi tepung porang termodifikasi dan analisis data.

\section{Pembuatan \\ Tepung \\ Termodifikasi}

Proses pembuatan tepung porang termodifikasi meliputi beberapa tahapan proses antara lain proses pengupasan, pencucian, pengecilan ukuran, fermentasi, pengeringan, penepungan dan pengayakan. Pada penelitian ini proses produksi tepung porang dilakukan dengan metode penggilingan (basah dan kering) dan variasi lama fermentasi 0, 6, 12, 18 dan 24 jam.

Langkah dalam pembuatan tepung porang yaitu umbi porang dikupas menggunakan pisau dengan tujuan memisahkan bagian kulit umbi. Selanjutnya umbi porang tersebut masuk pada tahap pencucian dengan menggunakan air. Tujuan 
proses pencucian ini adalah untuk menghilangkan kotoran yang menempel pada permukaan umbi porang. Setelah umbi porang bersih selanjutnya dilakukan pemotongan dengan alat slicer sehingga diperoleh bentuk chip. Chip umbi porang tersebut selanjutnya masuk pada tahap proses fermentasi dengan ketentuan waktu lama fermentasi yang bervariasi yaitu 6,12 , 18 dan 24 jam. Proses fermentasi dilakukan dengan menambahkan BAL dan air dengan perbandingan (1:1000) (Putri et al., 2018).

\section{Proses produksi dengan metode penggilingan kering.}

Metode penggilingan tepung porang secara kering dilakukan dengan pengeringan chip umbi porang yang telah difermentasi sebelumnya menggunakan sinar matahari (sun drying) sehingga dihasilkan chips umbi porang yang kering. Chips tersebut kemudian digiling dengan memakai alat penggiling blender dalam kurun waktu satu menit. Setelah itu tepung porang disaring menggunakan ayakan 100 mesh, sehingga diperoleh tepung porang termodifikasi dengan metode penggilingan kering.

\section{Proses produksi dengan metode penggilingan basah}

Berbeda halnya proses penggilingan tepung porang dengan metode penggilingan kering, metode penggilingan basah diproses dengan tahap permulaan yaitu penggilingan dengan menambahkan air melalui perbandingan (6:1). Penggilingan dilakukan menggunakan blender selama satu menit sehingga dihasilkan bubur umbi porang. Selanjutnya, bubur umbi tersebut difermentasi sesuai dengan ketentuan waktu yang ada $(6,12,18$ dan 24 jam) diwadah tertutup (anaerobik). Hasil fermentasi dikeringkan pada sinar matahari hingga kering dan bubur tepung porang termodifikasi tersebut menjadi kering. Bubur umbi porang yang kering tersebut kemudian digiling kembali dengan blender selama satu menit dan selanjutnya disaring dengan ayakan 100 mesh, kemudian dihasilkan tepung porang termodifikasi dalam bentuk kering dan seragam.

\section{Parameter Pengamatan}

Parameter pengamatan pada tepung porang termodifikasi yang dilakukan yaitu analisa fisik dan kimia. Analisa tepung porang termodifikasi secara fisik diantaranya pengujian warna dan uji organoleptik, sedangkan untuk analisa kimia yaitu kadar glukomanan, kadar kalsium oksalat dan analisa proksimat meliputi kadar air, kadar lemak, kadar serat kasar, kadar protein, kadar karbohidrat, dan kadar abu.

\section{Analisis Data}

Data diuji dengan ANOVA dan uji lanjut yang digunakan adalah uji BNT (Beda Nyata Terkecil) pada taraf 0,05. Data ditampilkan dalam bentuk tabel dengan nilai rata-rata analisis.

\section{HASIL DAN PEMBAHASAN}

\section{Kadar glukomanan}

Penentuan senyawa glukomanan pada tepung porang digunakan metode Nelson-Somogy (Sudarmaji et al. 1984). Sejumlah 9 sampel termasuk kontrol dengan perlakukan metode penggilingan dan variasi lama fermentasi sebanyak dua kali ulangan. Hasil analisa kadar glukomanan disajikan pada Gambar 1 dan Tabel 2. 


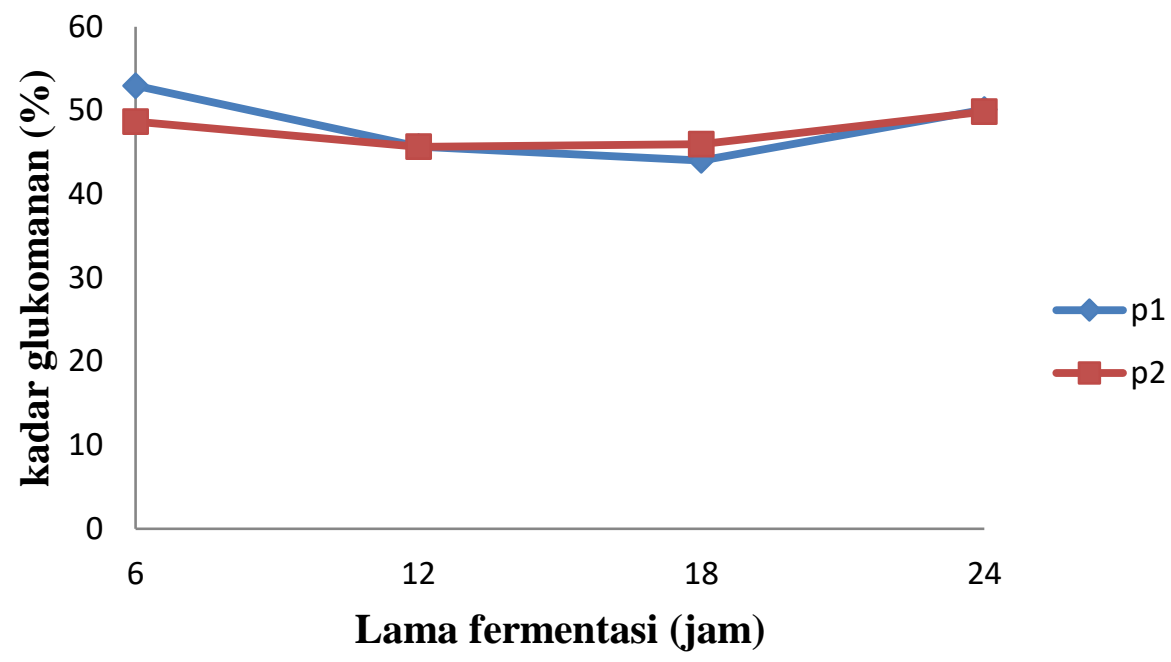

Gambar 1. Grafik hasil analisa kadar glukomanan tepung porang termodifikasi

Keterangan: P1 : Metode penggilingan basah

P2 : Metode Penggilingan kering

Tabel 2. Hasil Analisa kadar glukomanan

\begin{tabular}{cc}
\hline Jenis Perlakuan & Rata-rata Nilai kadar glukomanan \\
\hline T1P1 & $52,96 \pm 4,99$ \\
T2P1 & $45,69 \pm 2,62$ \\
T3P1 & $44,01 \pm 1,36$ \\
T4P1 & $50,13 \pm 5,07$ \\
T1P2 & $48,68 \pm 5,68$ \\
T2P2 & $45,96 \pm 5,57$ \\
T3P2 & $45,96 \pm 1,81$ \\
T4P2 & $49,86 \pm 3,59$ \\
\hline
\end{tabular}

Berdasarkan uji statistik terhadap kadar glukomaman diketahui bahwa tidak ada perbedaan signifikan dari perlakuan metode penggilingan dan lama fermentasi tepung porang termodifikasi pada taraf nyata $\alpha: 0,05$. Sehingga tidak dilakukan uji lanjut BNT. Berdasarkan Gambar 1 mengenai grafik hasil analisis kadar glukomanan tepung porang termodifikasi diketahui terdapat hasil yang menunjukkan perbedaan pada kedua metode penggilingan basah dan penggilingan kering pada lama fermentasi 12 jam yaitu secara berurutan sebesar 45,68 dan 45,65\%. Namun selanjutnya mengalami peningkatan pada lama fermentasi 24 jam sebesar 50,12 dan 49,86\%. Kandungan glukomanan yang berbeda pada setiap bahan atau sampel lebih disebabkan oleh tahapan proses dan cara pengolahan. Proses dalam pencucian setelah dilakukan fermentasi menyebabkan beberapa kandungan glukomanan terlarut dan tercuci.

Faktor kandungan kadar glukomanan yang tinggi lebih disebabkankan karena beberapa hal diantaranya adalah faktor umur, cara atau teknik pengolahan dan lama penyimpanan. Hasil analisis terhadap kadar glukomanan tepung porang termodifikasi memiliki nilai yangcenderung tinggi yaitu berada pada kisaran $44-52 \%$. Kandungan glukomanan tepung porang hasil penelitian diketahui berada dikisaran $47-52 \%$ (Handayani et al. 2020). Berdasarkan SNI 7939-2013 
diketahui tepung porang modifikasi hasil penelitian masuk kedalam kategori mutu I. Kadar glukomanan yang terdapat pada tepung porang termodifikasi tinggi menandakan tingginya mutu tepung tersebut, karena manfaat tepung porang banyak diambil dari kandungan glukomanannya (Handayani et al., 2020).

\section{Kadar kalsium oksalat}

Penentuan senyawa kalsium oksalat pada tepung porang digunakan metode Titrasi Permanganometri (Handayani et al., 2020). Sejumlah 8 sampel dengan perlakukan metode penggilingan dan lama fermentasi dengan dua kali ulangan. Hasil analisa kadar kalsium disajikan pada Gambar 2 dan Tabel 3.

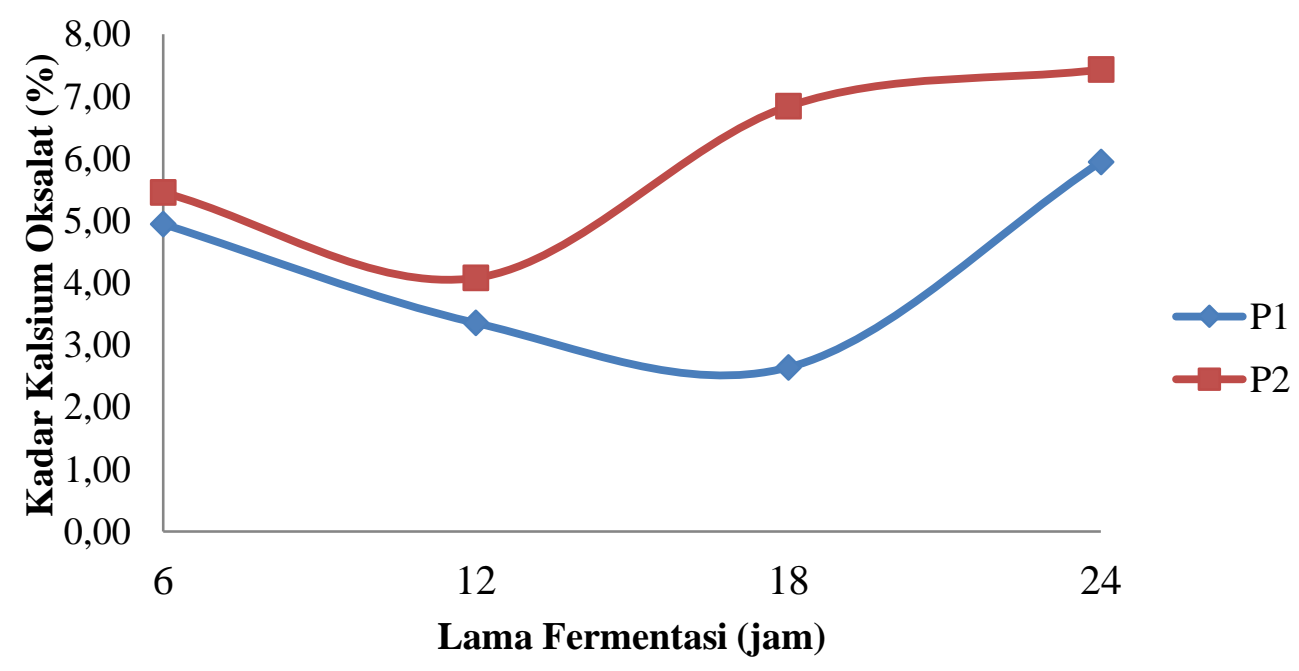

Gambar 2. Grafik hasil analisa kadar kalsium oksalat tepung porang termodifikasi Keterangan: P1 : Metode penggilingan basah P2 : Metode Penggilingan kering

Tabel 3. Hasil Analisa kadar kalsium oksalat

\begin{tabular}{cc}
\hline Jenis Perlakuan & Rata-rata Nilai kadar oksalat \\
\hline T1P1 & $4,95 \pm 0.01^{\mathrm{a}}$ \\
T2P1 & $3,36 \pm 0.54^{\mathrm{ab}}$ \\
T3P1 & $2,64 \pm 1.24^{\mathrm{bc}}$ \\
T4P1 & $5,95 \pm 0.94^{\text {ad }}$ \\
T1P2 & $5,46 \pm 0.22^{\text {ade }}$ \\
T2P2 & $4,08 \pm 1.40^{\text {abce }}$ \\
T3P2 & $6,84 \pm 0.62^{\text {def }}$ \\
T4P2 & $7,43 \pm 0.40^{\text {def }}$ \\
\hline
\end{tabular}

Keterangan: Angka yang diikuti oleh huruf yang sama pada kolom yang sama tidak berbeda nyata berdasarkan uji Beda Nyata Terkecil (BNT) pada taraf 5\%.

Berdasarkan uji statistik terhadap kadar kalsium oksalat diketahui bahwa terdapat pengaruh signifikan dari perlakuan metode penggilingan dan lama fermentasi tepung porang termodifikasi pada taraf nyata $\alpha$ : 0.05. Berdasarkan Gambar 2 mengenai grafik hasil analisa kadar kalsium oksalat tepung porang termodifikasi diketahui terdapat hasil yang menunjukkan perbedaan pada perlakuan metode penggilingan basah dengan lama fermentasi 18 jam dengan total kadar kalsium oksalt sebesar 2,64\%. Namun semakin lama waktu fermentasi menyebabkan kandungan kalsium oksalat 
kembali meningkat. Hasil penelitian menunjukkan bahwa penurunan kandungan kalsium oksalat berada pada nilai $62,28 \%$. Hasil ini lebih baik dibandingkan dengan penelitian sebelumnya yang dilakukan oleh Wardani dan Handrianto (2019) yang melakukan penelitian untuk menurunkan kadar kalsium oksalat dengan melakukan perendaman terhadap umbi porang dengan sari belimbing wuluh. Sari belimbing wuluh diketahui memiliki kandungan asam organic tinggi yang mampu melarutkan kandungan kalsium oksalat pada tepung porang. Hasil penelitian tersebut menunjukkan bahwa terjadi penurunan optimal kandungan kalsium oksalat pada umbi porang (3.084\%) menjadi $(1.47 \%)$ atau penurunan sebesar $47 \%$ kalsium oksalat setelah dilakukan perendaman pada sari belimbing wuluh dengan konsentrasi $7 \%$.

Kalsium oksalat tergolong zat berbahaya bagi tubuh apabila dikonsumsi oleh mahluk hidup. Kandungan kalsium oksalat pada tepung porang ini menyebabkan rasa gatal dan ketika diekstraksi akan mempengaruhi kualitas tepung glukomanan, sehingga perlu dilakukan penurunan kadar kalsium oksalat melalui proses pengolahan yang baik (Nurenik, 2016).

\section{Kandungan proksimat tepung porang termodifikasi}

Sampel yang digunakan dalam analisa proksimat merupakan sampel dengan hasil penurunan kadar kalsium oksalat paling optimal yaitu pada perlakuan metode penggilingan basah serta perlakuan lama fermentasi 18 jam. Uji proksimat yang dilakukan meliputi kadar air, kadar protein, lemak, abu dan karbohidrat. Hasil analisa proksimat tepung porang termodifikasi disajikan pada Tabel 4.

Tabel 4. Hasil analisa proksimat tepung porang termodifikasi

\begin{tabular}{clcc}
\hline No & Komposisi kimia & Rata-rata kandungan (\%) & SNI 7939;2013 (\%) \\
\hline 1 & Protein (\%) & 9,34 & $5-14 \%$ \\
2 & Lemak (\%) & 0,49 & \\
3 & Air (\%) & 12,50 & $13 \%$ \\
4 & Abu (\%) & 3,59 & $4 \%$ \\
5 & Karbohidrat (\%) & 74,09 & \\
\hline
\end{tabular}

Beberapa parameter menunjukkan bahwa kandungan proksimat protein, air dan abu telah memenuhi standar mutu yang telah ditetapkan untuk tepung porang (SNI 7939;2013). Kandungan proksimat hasil analisa menunjukkan kadar protein, lemak, air, abu dan karbohidrat secara berurutan adalah $9,34 \%, 0,49 \%, 12,50 \%, 3,59 \%$ dan $74,09 \%$.

\section{Karakteristik fisik dan uji organoleptik}

Karakteristik fisik tepung porang termodifikasi dilakukan secara kualitatif dengan uji sensori menggunakan panca indera terhadap beberapa parameter yaitu warna, aroma, bentuk, dan rasa. Sedangkan pengujian warna diketahui dengan menggunakan chromameter U dengan sistem warna Hunter L* (warna putih), a* (warna merah), $b^{*} \quad$ (warna kuning). Hasil pengamatan fisik dan uji warna tepung porang termodifikasi disajikan pada Tabel 5 . 
Tabel 5. Hasil pengamatan fisik dan uji warna tepung porang termodifikasi

\begin{tabular}{|c|c|}
\hline Parameter & Pengamatan \\
\hline Warna (sensori) & Putih kecoklatan \\
\hline Aroma & Aroma khas tepung \\
\hline Bentuk & Serbuk \\
\hline Rasa & Agak asin \\
\hline \multicolumn{2}{|l|}{ Warna: } \\
\hline $\mathrm{L}$ & 54,85 \\
\hline$a^{*}$ & 14,25 \\
\hline$b^{*}$ & 17,55 \\
\hline
\end{tabular}

Hasil penilaian secara kualitatif dengan panca indera menghasilkan warna tepung porang berupa putih kecokelatan, aroma khas tepung, bentuk berupa sebuk dan rasa cenderung agak asin. Warna merupakan salah satu faktor fisik yang mempengaruhi tingkat estetika. Gabungan nilai a yang tinggi dan nilai $b$ yang rendah menghasilkan tepung porang dengan warna kusam (cokelat) sedikit putih sehingga menghasilkan tingkat kecerahan yang rendah, sedangkan nilai a rendah dan $\mathrm{b}$ tinggi menunjukkan warna kuning cerah (Rosmisari, 2006).

\section{KESIMPULAN}

Berdasarkan hasil penelitian dapat disimpulkan bahwa teknologi pembuatan tepung porang termodifikasi dengan penurunan kadar kalsium oksalat tertinggi adalah perlakuan metode penepungan dengan penggilingan basah dan lama fermentasi 18 jam dengan nilai 62,28\%. Karakteristik kimia berupa kandungan proksimat tepung porang termodifikasi hasil analisa menunjukkan kadar protein, lemak, air, abu dan karbohidrat secara berurutan adalah 9,34\%, 0,49\%, 12,50\%, 3,59\% dan $74,09 \%$. Karakteristik fisik tepung porang berupa putih kecokelatan, aroma khas tepung, bentuk berupa sebuk dan rasa cenderung agak asin.

30 | Jurnal Agroindustri Vol. 11 No. 1, Mei 2021: 23-31

\section{UCAPAN TERIMAKASIH}

Artikel ini merupakan hasil dari penelitian dosen pemula (PDP) tahun 2020 yang didanai oleh Direktorat Riset dan Pengabdian Kepada Masyarakat, Direktorat Jenderal Penguatan Riset dan Pengembangan Kementerian Riset, Teknologi dan Badan Riset Inovasi Nasional.

\section{DAFTAR PUSTAKA}

Agustin, R., T. Estiasih, dan A.K. Wardani, (2017). Penurunan oksalat pada proses perendaman umbi kimpul (Xanthosoma sagittifolium) di berbagai konsentrasi asam asetat. Jurnal Teknologi Pertanian, 18(3), 191-200.

Arifin, M. A. (2001). Pengeringan Kripik Umbi Iles-Iles Secara Mekanik untuk Meningkatkan Mutu Keripik Iles-Iles. Teknologi Pasca Panen. PPS. IPB. Bogor.

Faridah, A., S.B. Widjanarko, A. Sutrisno, dan B. Susilo. (2012). Optimasi produksi tepung porang dari chip porang secara mekanis dengan metode permukaan respons. Jurnal Teknik Industri, 13(2), 158-166.

Harijati, N., E. L. Arumingtyas, dan R. Handayani. (2011). Pengaruh 
pemberian kalsium terhadap ukuran dan kerapatan kristal kalsium oksalat pada porang (Amorphophallus muelleri blume). Jurnal Pangan dan Agroindustri 1(2), 72-139.

Handayani, T., Y.S. Aziz dan D. Herlinasari. (2020).Pembuatan dan uji mutu tepung umbi porang (Amorphophallus Oncophyllus Prain) di Kecamatan Ngrayun. Jurnal Medfarm: Farmasi dan Kesehatan 9(1), 13-21.

Leko, A., V.N. Lawalata, dan S.J. Nendissa. (2018). Kajian penambahan konsentrasi susu skim terhadap mutu minuman yogurt dari limbah air cucian beras local. AGRITEKNO, Jurnal Teknologi Pertanian. 7(2), 49-55.

Muhtarom, I. (2021). Porang primadona baru pasar ekspor, permintaan dari luar negeri terus meningkat. https://bisnis.tempo.co/read/1452510/ porang-primadona-baru-pasar-eksporpermintaan-dari-luar-negeri-terusmeningkat [diakses tanggal 28 April 2021]

Nakata, P.A. (2003). Advances in our understanding of calcium oxalate crystal formation and function in plant. Journal Plant Science 164, 901-909.

Putri, N.A., H. Herlina, dan A. Subagio. (2018). Karakteristik mocaf (Modified Cassava Flour) berdasarkan metode penggilingan dan lama fermentasi. Jurnal Agroteknologi, 12(1), 79-89.

Sitompul, M.R., F. Suryana, D.S. Bhuana, dan Mahfud. (2018). Ekstraksi asam oksalat pada umbi porang (Amorphophallus oncophyllus) dengan metode mechanical separation. JURNAL TEKNIK ITS, 7(1),135-137.

Rosmisari, A. (2006). Review: Tepung jagung komposit, pembuatan dan pengolahannya. Prosiding Seminar Nasional Teknologi Inovatif
Pascapanen Pengembangan Pertanian. BPPPT. Bogor.

Subagio, A. (2006). Ubi kayu substitusi berbagai tepung-tepungan. Food Review, 1(3), 18-22.

Sudarmaji S, B. Haryono, dan Suhardi. (1984). Prosedur untuk bahan makanan pertanian. Edisi ke 3 . Liberty. Yogyakarta.

Wardani, R. K. dan handrianto, P. (2019). Pengaruh perendaman umbi dan tepung porang dalam sari buah belimbing wuluh terhadap sifat fisik dan kadar kalsium oksalat. Journal of Pharmacy and Science, 4(2), 105-109.

Widari, N. S. dan A. Rasmito. (2018). Penurunan kadar kalsium oksalat pada umbi porang (Amorphopallus oncophillus) dengan proses pemanasan di dalam larutan $\mathrm{NaCl}$. Jurnal Teknik Kimia, 13(1), 1-4.

Widjanarko, S.B. (2011). Kajian metode ekstraksi konvensional baru dan ultrasonik dalam purifikasi glukomannan dari umbi porang (Amorphopallus oncophyllus) dalam upaya menghasilkan produk bahan tambahan pangan dan pangan fungsional baru. Penelitian. Universitas Brawijaya. Malang. 